IZA DP No. 6479

Do Unions Promote Members' Electoral Office Holding? Evidence from Correlates of State Legislatures'

Occupational Shares

Aaron Sojourner

April 2012 


\title{
Do Unions Promote Members' Electoral Office Holding? Evidence from Correlates of State Legislatures' Occupational Shares
}

\author{
Aaron Sojourner \\ University of Minnesota \\ and IZA
}

Discussion Paper No. 6479

April 2012

IZA

P.O. Box 7240

53072 Bonn

Germany

Phone: +49-228-3894-0

Fax: +49-228-3894-180

E-mail: iza@iza.org

\begin{abstract}
Any opinions expressed here are those of the author(s) and not those of IZA. Research published in this series may include views on policy, but the institute itself takes no institutional policy positions.

The Institute for the Study of Labor (IZA) in Bonn is a local and virtual international research center and a place of communication between science, politics and business. IZA is an independent nonprofit organization supported by Deutsche Post Foundation. The center is associated with the University of Bonn and offers a stimulating research environment through its international network, workshops and conferences, data service, project support, research visits and doctoral program. IZA engages in (i) original and internationally competitive research in all fields of labor economics, (ii) development of policy concepts, and (iii) dissemination of research results and concepts to the interested public.
\end{abstract}

IZA Discussion Papers often represent preliminary work and are circulated to encourage discussion. Citation of such a paper should account for its provisional character. A revised version may be available directly from the author. 


\section{ABSTRACT}

\section{Do Unions Promote Members' Electoral Office Holding? Evidence from Correlates of State Legislatures' Occupational Shares*}

Controversies over the promise and perils of union political influence have erupted around the U.S. This study develops the first evidence on the degree to which labor unions develop members' political leadership in the broader community by studying the relationship between state legislators' occupations and the unionization rates of occupations across U.S. states. The fraction of legislators of a given occupation in a state increases with the occupation's rate of unionization in that state compared to the fraction of legislators of the same occupation in other states with lower unionization rates. This pattern shows up to varying degrees among the three public-sector and one private-sector occupations considered: K-12 teachers, police officers, fire fighters, and construction workers. It holds conditional on differences in observable state characteristics and when using state fixed effects. While much research has described the role of unions in influencing economic outcomes and in politics through lobbying, campaign contributions, and voter mobilization, this work adds a new perspective on the role of unions in society. They promote elected political leadership by individuals from working- and middle-class jobs. Arguments over the social value of this role of unions are explored.

JEL Classification: D7, H7, J5

Keywords: union, elected office, teachers, police, construction, public-sector

Corresponding author:

Aaron Sojourner

University of Minnesota

Carlson School of Management

Department of Work and Organizations

321 Nineteenth Avenue South 3-300Y

Minneapolis, MN 55455-0438

USA

E-mail: asojourn@umn.edu

\footnotetext{
* Thanks to Kathleen Cassidy, who helped me recognize this topic as useful to pursue, to Gregory Budd, Arlene Schuweiler, and Qianyun Xie for excellent research assistance, and to John Budd, Brian Hagerty, Ryan Lamare, Colleen Manchester, and Elton Mykerezi for their feedback.
} 
"Corporate America is very good at electing their people. If it's good for them, why can't it be good for us?"

- $\quad$ New Jersey State AFL-CIO President Charles Wowkanech (Perez-Pena 2010).

This study calls attention to a neglected effect of unions - they help members rise to elected public office - and assesses its magnitude empirically. This role of unions is part of larger debates over the promise and perils of union political influence playing out in Wisconsin and elsewhere (Mullans and McKinnon 2010, Greenhouse 2011). On one side is concern that unions use political influence to bend policy to serve their own special interests at the expense of the public interest. This concern is particularly salient regarding public-sector unions. The other side views union political influence generally and members serving in public office as socially constructive for three primary reasons: to help unions act as a counter-weight to the policy influence of organized capital; to improve the quality of legislatures' deliberations through increased diversity; and to promote members' personal development.

Developing quantitative evidence on the extent to which unions help members rise to elected office is challenging. Using publicly available information, researchers cannot reliably and consistently observe whether a particular elected official has belonged to a union or not. Elected officials choose whether or not to advertise this fact. A failure to report may indicate either nonmembership or political inconvenience. Furthermore, because the probability of any particular person being elected to office is very low, one needs to study large populations.

Given these constraints, what ideal experiment would one like to run to test the theory that unionization causes office holding among members? Take multiple polities that each contains an identifiable group of potential candidates for office. In each polity, randomly assign members of the identifiable group to have a particular unionization rate. Later, observe whether or not members of the group hold a greater share of public offices where they were more unionized.

This thought experiment helps to clarify the current study's research question and the strengths and weaknesses of its design. A cross-section of the 50 U.S. states are the multiple polities. Occupations define the identifiable groups of potential candidates with various levels of unionization. This study focuses on people in three public sector occupations $-\mathrm{K}-12$ teachers, 
police officers, and fire fighters - and one private sector occupation, construction workers. The outcome is the occupational share of state legislative seats held. For example, given that teachers are more highly unionized in Minnesota than Mississippi, are Minnesota legislators more likely to be teachers than Mississippi legislators? While unionization rates vary across states and occupations, they are obviously not randomly assigned. This raises the possibility of omitted variables that could drive both occupational unionization and electoral success for a given state-occupation, as well as possible reverse causality, whereby a given occupation having more electoral success in a state leads to greater unionization. To address these concerns, the analysis conditions on observed state differences and, in some specifications, uses state fixed effects to remove unobserved state differences that are common across the four occupations.

\section{How Unions Support Members' Rise to Public Office}

Unions may help their members rise to public office through three key processes. First, individual members may develop their personal skills as political leaders by participating in the internal organizational life of the union. Union members have chances to build leadership and political skills as they participate in the life of the organization (Quaglieri 1988; Eaton 1995; Nesbitt 2001). They gain valuable and, for some, rare experience making collective decisions, using parliamentary procedure, bargaining for high stakes, engaging in public speech and persuasion, and building coalitions to seek internal union office. This experience builds necessary skills for public leadership. Second, because unions pursue members' collective objectives in the larger community through politics and policy, unions facilitate and encourage policy engagement by members. Once bitten by the bug, some members feel compelled to seek a larger role. Third, if an individual member wants to run for public office, her own union and the broader local labor movement serve as a base from which to launch a campaign.

While each of these three processes has been described to some extent by previous research, they have not been linked together as precursors to members' public office holding nor have prior studies attempted to quantify the effect of unions on office holding among members. In a qualitative account of the Los Angeles Central Labor Council, Frank and Wong (2004) describes the phenomenon anecdotally and discusses how it fits into a broader political strategy. There is 
also a lot of work on the economic effects of unions (Freeman and Medoff 1984; Lewis 1986; Addison and Hirsch 1989; DiNardo and Lee 2004; Hirsch 2004; Mas and Lee 2009) and on unions' political roles in mobilizing voters (Delaney et al 1988; Radcliff and Davis 2000; Freeman 2003; Zullo 2008; Lamare 2010a and 2010b), contributing resources to campaigns, and lobbying (Freeman and Medoff 1984; Masters and Delaney 1988; Delaney et al 1988; Dark 2000; McDermott 2006). In countries with a labor party, the rise of members to public office is common but in the U.S., it has not received much attention.

Approaching the question from a different angle, Sanbonmatsu et al (2009) report evidence suggestive of the importance of labor unions in supporting members' candidacies. They surveyed a sample of state legislators about their pathways to office and found that about 20 percent of Democratic and 14 percent of Republican state representatives were active in a "teachers' organization" prior to running for office the first time. Additionally, more than 20 percent of Democratic and 6 percent of Republican representatives report involvement with a "labor organization" prior to running for office. For comparison, more than 50 percent of representatives report involvement with "business or professional organizations." This suggests that involvement with professional organizations generally and labor organizations specifically are common precursors to office holding. However, without comparable measures in the population at large, it is not clear whether legislators are disproportionately active in such organizations or not. Even if they are disproportionately active, it is not clear which way causality runs. Do political aspirants tend to join organizations or do organizations help elevate their members to public office?

Electing members to public office is a strategic priority for many in the labor movement. Across the country, the AFL-CIO's “Target 5000” program explicitly aims to train and to support members in attaining public office, as did its precursor "2000 in 2000" program, and as do many other internal union programs (Work in Progress 2001, Bayne 2011, Massachusetts AFL-CIO 2011, McCabe 2011). An October 2010 New York Times article about the New Jersey AFLCIO's candidate training program highlights many of the themes motivating the current study (Perez-Pena 2010),

"These people running for town councilman, mayor, county freeholder and other posts are graduates of a state A.F.L.- C.I.O. boot camp that has been more successful than any other such 
effort in the nation at recruiting, training and supporting union members who run for elective office....

“'Without my union and the support of the A.F.L.-C.I.O., I wouldn't be here,' said [James M. Carroll who is a candidate for office, member of the International Brotherhood of Electrical Workers, and graduate of the A.F.L.-C.I.O. program.]

"Even labor's political opponents expressed admiration. 'The political parties supposedly try to do the same thing, to groom candidates from the grass roots, but the A.F.L.-C.I.O. does it more effectively,' said Richard J. LaRossa, a Republican former state senator who leads a conservative policy group, Solutions for New Jersey."

Trainees attend two-days of classes by politicians and political consultants. The training program is free for trainees and reportedly costs the state AFL-CIO about $\$ 250,000$ per year. In contrast, the New Jersey AFL-CIO made only $\$ 25,000$ in direct campaign contributions to candidates for state offices in 2009 (Followthemoney.org 2012), a more commonly studied and understood union political tactic. Outside of formal candidate training programs, unions routinely engage in political action. Where union members are candidates, they will often benefit from union support provided through endorsements, financial contributions, communications campaigns, field volunteers and voter mobilization.

Studying this phenomenon in state legislatures makes sense because of the availability of data on legislator occupations and occupational unionization rates at this level. However, there is every reason to think the process operates at lower levels of government. In particular, the New Jersey AFL-CIO lists 334 union members in elected public office in New Jersey. Of these, only 5 are state legislators. The others are primarily mayors or members of school boards, fire district boards, or town councils.

\section{Issues at Stake}

Promoting the election of union members to public office is one tactic employed by unions as part of the labor movement's broader strategy to shape public policy. Therefore, this particular role of unions is part of a larger debate about the promise and perils of union political influence. In the pluralist political tradition, various organized interests are seen as contenders to influence policy. A healthy system is a balanced system, where no narrow segment of society exerts 
excessive influence (Madison 1787). Much of the controversy about union political influence in general revolves around who poses a greater risk to the health our democracy and our economy: organized labor or organized wealth. In addition to these general concerns about union political influence, this specific tactic raises some specific issues that do not apply to other parts of labor's political strategy. Three arguments in favor of this role as socially productive are described below as well, as the main arguments against it. Many of these arguments play out in campaigns when union members run for public office, as examples will illustrate.

The first argument on the positive side begins with the premise that unchecked, concentrated wealth can lead to oligarchic politics, where wealthy interests have disproportionate influence on policy and where diffuse, collective interests are underrepresented (Commons 1934, Galbraith 1952, Olson 1965, Acemoglu 2008). By organizing the resources of millions of working Americans and focusing them on policy issues, unions have been one of the most consistent, powerful forces driving for progressive or liberal public policies (Pierson and Hacker 2011). In this, unions have been motivated by both a principled view of workers' rights and a selfinterested recognition that extending pro-labor standards to the nonunion sector through public policy makes unions easier to maintain.

Organized labor often conflicts with organized advocates of deregulation, low taxes, special breaks and protections for incumbent firms, and the rights of capital. These include the owners and managers of individual companies and federations of companies, such as Chambers of Commerce and the National Association of Manufacturers. In addition, a long line of wealthy magnates from Jay Gould to the Koch brothers have commanded large fortunes, influenced the politics and policies of their day, and commonly clashed with labor.

In the absence of unions, workers may have a difficult time overcoming collective action problems, cooperating to pursue their shared policy interests, and serving as an effective counterweight to the capture of public policy by other concentrated economic interests. Smaller groups act to joint ends more readily than larger groups do. Smith (1776) noted this tendency in economic conflicts, "The masters, being fewer in number [than the workmen], can combine much more easily." Key (1942), a seminal work on pressure groups, remarked, 
"The holders of wealth, whatever its form, have great stakes in the outcome of political struggles; they also have the time to devote to political maneuver or the money to employ others to do so. The power wielded by business in American politics may puzzle the person of democratic predilections: a comparatively small minority exercises enormous power... Labor assaults the business citadel from time to time with varying degrees of success. Yet, withal, business retains a position of potent leadership in public affairs."

Capital has another advantage in policy fights vis-a-vis labor and consumers; it is distributed very unequally and so there are wealthy individuals and corporations with large stakes in policy fights. Olson (1965) points out a subtle but very important fact: it is easier for a group to produce a collective good (i.e., a policy reform that will benefit the group) if benefits are divided unequally and there are a few actors in the group who expect to reap disproportionate benefit. ${ }^{2}$ In a policy fight between concentrated wealth and diffuse workers or consumers, the few large players will have disproportionate and potentially socially corrosive success. No single worker or consumer could marshal enough resources to act as effectively. With income and wealth becoming increasingly concentrated (Piketty and Saez 2003), recent legal changes widening the role for money in politics (Citizens United 2010; Quist 2012), and a weakening labor movement, concerns about the health of our democracy are rising and the problems of inequality. In particular, helping working and middle-class Americans develop into civic and political leaders may be a channel for unions to play a counter-weight role.

Second, a legislature filled with individuals from diverse occupational and economic backgrounds may make better law than one drawn from a narrow segment. Well-off individuals disproportionately have many valuable skills that make them attractive candidates to voters. They also have greater access to resources to support a political candidacy. However, a legislature drawn exclusively from society's upper ranks risks narrowness. Important information about life from other perspectives might not make it into deliberations (Hinsz et al 1997). As institutions that help working and middle class Americans overcome free-riding in pursuit of their joint interests by helping members rise to elected office, unions may increase the completeness of legislative deliberations.

\footnotetext{
${ }^{2}$ For instance, suppose there 100 firms with an interest in changing a policy. If it changes, it will raise their total profits by $\$ 100$ million. Running a successful lobbying operation will cost $\$ 30$ million. If the $\$ 100$ million in benefits would be shared equally, they need at least 30 firms to cooperate, agree on strategy, and contribute. On the other hand, if 1 firm stands to reap $\$ 50$ million and the other 99 would split the other $\$ 50$ million, then the single firm that stands to reap the large gain would ensure the lobbying operation occurs. 
Third, union support for members' personal development as political leaders may be valued in service to producing a vibrant democratic citizenry. Unions are not unique in supporting members' rise to political leadership in the broader community. They share this feature with many other democratically-governed institutions in society (Skocpol 2003, Bagetta 2009). Networks of faith communities play similar roles for their members and conservative candidate training schools have been especially active (Deckman 2004). Other professional associations and networks play these roles for doctors, lawyers, scientists, or business executives. However, for people in working- and middle-class jobs, unions have been the primary organizations available centered on economic issues.

On the negative side, unions do in part use their policy influence at the expense of the public interest and unions' success in elevating members to public office may play a role in this. In this view, unions are the concentrated special interest that attempt to bend policy their way at the expense of capital, consumers, the unemployed, and tax-payers (Olson 1965, Rose 1987). As Reynolds (1984) put it, "Unions, continuously battling the erosion of their privileged positions, urge new political regulations and restrictions, thereby reducing both the free flow of capital and labor and the efficiency of the economy." This is an aspect of union's monopoly face (Freeman $\&$ Medoff 1984). The same New Jersey Republican State Senator who praised the effectiveness of the New Jersey AFL-CIO's member candidate training program lamented its effects on state policy this way,

"Mr. LaRossa and other critics contend that the unions' electoral success contributes to the high cost of government in New Jersey, a core issue in a state where Gov. Chris Christie, a Republican, has clashed with labor and lawmakers over salaries, pensions, staffing and overlapping layers of government. 'The labor agenda is pay more, build more, hire more, spend more,' Mr. LaRossa said.” (Perez-Pena 2010)

Theoretically and politically, this concern is particularly acute regarding public-sector unions. Public-sector unions may have a special ability to advance members' interests at the expense of the public, since they may sit across the bargaining table from political allies in elected office (Gregory and Borland 1999). Moe (2011) argues this perspective forcefully and exhaustively, especially as it pertains to teachers' union activism in school board elections. In a particularly vivid example, he cites a piece of political education literature from the Michigan teachers union 
titled, "Elect Your Own Employer, It's as Easy as 1, 2, 3." Despite this, other recent studies find evidence that public-sector union affect policy outcomes very little or not at all (Lovenheim 2009, Frandsen 2011).

A clear example of the controversy over union members' fitness as candidates for public office flared as part of the 2011 battle over public-sector employee bargaining rights in Wisconsin. These themes came to the fore when Wisconsin teachers union leader Shelly Moore challenged incumbent Republican Wisconsin State Senator Sheila Harsdorf in a recall election. News articles (Umhoefer 2011) and campaign videos centered on Moore's role as a union teacher and how this affected her potential as a legislator. Moore's advocates emphasized that her experience as a teacher had led her to support policies that would benefit the state economy. "Shelly Moore, a lifelong teacher, knows that education is the key to a bright future for our children and our state. Moore is committed to protect funding for our schools because she recognizes that better schools will help provide more opportunities for jobs and education here in Wisconsin." (WeAreWisconsinPac 2011).

Opponents of Moore explicitly attacked her union involvement, emphasizing anti-union images, and arguing that she posed a threat to the state's fiscal health. One illustrative example was a video of featuring Moore addressing a Wisconsin Educational Association Convention (WEAC) assembly accompanied by text stating that, "Her special interest friends at WEAC intimidate and threaten those that don't go along with their tax and spend agenda. Our own 'Wisconsin Mafia'..." (Mooretaxes 2011). ${ }^{3}$

The campaign rhetoric echoes these debates about the virtue of union political influence. Having described the process by which unions support members' rise to public office and discussed the central social issues swirling around this phenomenon, I next turn to describing the design of the empirical analysis and the results, which offer the first quantitative evidence about its magnitude.

\footnotetext{
${ }^{3}$ A second similar example is the current race for Pennsylvania's 131st State House district where Former local teacher's union president Kevin Deely is challenging incumbent Justin Simmons (Lester 2012). Deely's rhetoric is similar to that of Wisconsin's Moore. Says Deely, "We can't keep cutting funding to things like education and leaving our children behind in this economy.... I have worked for and advocated for teachers and the profession, I don't think it's a bad thing. Certainly there are other things I care about other than education...I certainly do support working men and women." As did Moore's opponents, Simmons argues that Deely will not serve the public interest. Simmons called Deely "a front man for special interest groups, fighting for one thing and that is for the [Pennsylvania State Education Association].” Other examples of these campaign themes are easy to find.
} 


\section{Study Design}

The study is designed to rest an empirical prediction of the theory that unions help members rise to elected office. Specifically, it tests whether members of a particular occupation are more likely to hold elected office if the occupation's unionization rate is higher. To this end, I collected occupational data on all state legislators around the country. I limit my analysis to occupations that had non-negligible propensities for both (1) unionization and (2) election to state legislatures and are also relatively well-defined, homogeneous across states, and identifiable in both legislator occupational data and national unionization data. ${ }^{4}$ I focus on four occupations that meet all these criteria: K-12 teacher, law enforcement officer, fire fighter, and construction worker. Three are primarily public sector and one private sector (construction worker). By looking across each legislator's occupational history, each state's share of legislators who ever worked in that occupation is measured. ${ }^{5}$

There is some evidence that the four occupations studied here cover a large share of the union members in state legislatures. In my research, I found lists of union members serving as state legislators for 3 states: Minnesota, New Jersey, and Oregon (Workday Minnesota 2006, Nothwest Labor Press 2008, New Jersey AFL-CIO 2012). Together these sources list 64 union member/legislators. Of these, $42(66 \%)$ have worked in one of the 4 focal occupations. The other $22(34 \%)$ are scattered over many other occupations and industries.

Why focus on state legislators rather than other elected officials? Substantively, they are important policy and political leaders. Methodologically, state legislators are interesting because their occupational data is consistently available across polities, i.e. states, (not true for lower offices) and there are dozens of them in every state allowing for meaningful variation in the occupational shares across polity (not true for higher offices). For each occupation-state, I construct measures of the percentage of workers in that occupation-state belonging to unions to

\footnotetext{
${ }^{4}$ For instance, though lawyers make up a large share of legislators, they would not be good subjects because few are unionized. Inversely, though janitors are often unionized, they would not be good subjects because they are rarely elected to legislatures.

${ }^{5}$ Attempts to generate measures of legislators' occupational experience in health care (but not exclusively as executives or doctors) and manufacturing yielded few legislators with measurable experience in these sectors. Either there are very few or it is very difficult to define satisfactory search criteria to parse the textual data.
} 
measure union strength. This unionization rate is the primary explanatory variable. Other measures of occupation-state and state characteristics are used as conditioning variables to isolate the primary relationship as much as possible.

The following linear model is used to measure the relationship between propensity to serve in the legislature and unionization rate across states indexed by $s$ and occupations indexed by $o$ :

$$
y_{o s}=\alpha u_{o s}+\beta e_{o s}+\gamma x_{s}+\delta_{s}+\pi_{o}+\varepsilon_{o s}
$$

The outcome is the fraction of state legislators, including state representatives and state senators, who have previously worked in a particular occupation $\left(y_{o s}\right)$. To construct this measure, biographical data on each state representative and each state senator in the country was downloaded from Project Vote Smart in July 2010. These include professional experience for each legislator. Usually, multiple past jobs with occupation and employer are listed. From this occupational history, I constructed four indicators measuring whether each legislator had ever worked as a K-12 teacher or staff member, a law enforcement officer, a professional fire fighter, or a construction worker. Those with experience in these industries only as managers were not included, as they are unlikely to have belonged to a union. Aggregating to the state level, I then construct the share of each state's legislators who have come from the occupation. ${ }^{6}$

As the top panel of Table 1 describes, states have on average 3.7 percent of legislators with experience as construction workers and states range between 0 and 13.3 percent of legislators having experience as construction workers. The average share of legislators across states for fire fighters is 1.1 percent, law enforcement is 3.2 percent, and $\mathrm{K}-12$ teacher is 12.4 percent.

The explanatory variable of primary interest is the union membership rate for each occupation and state $\left(u_{o s}\right)$. This comes from the Current Population Survey (CPS) using the methods of Hirsch and Macpherson (2003). All CPS observations from 2000-2009 are pooled for each stateoccupation to reduce measurement error in this cross-sectional variable. Unionization rates for the four occupations considered are listed in the second panel of Table 1.

\footnotetext{
${ }^{6}$ If no professional experience was listed for particular legislators, web searches were performed to attempt to learn about legislators' professions. If this failed, the occupational indicators were assumed to be missing at random and those individuals were excluded from the analysis. Occupational shares were computed using those with any observed professional experience as the denominator. Across states, only $3.4 \%$ of legislators are missing occupational data on average.
} 
Legislator shares $\left(y_{o s}\right)$ also likely depend on employment shares for each state-occupation $\left(e_{o s}\right)$. For instance, if teachers make up a larger fraction of the adult population, teachers are also likely to make up a larger share of the legislature apart from unionization rate. Therefore, I will condition on employment share to avoid this potentially confounding factor, using measures constructed from the CPS. Employment shares are listed in the third panel of Table 1. For instance, on average, states have 4.1 percent of their labor force working in construction. Occupations vary in the skills required and the kinds of people they are likely to attract. By focusing on variation across states within occupations, occupational differences can be controlled. Occupation fixed effects are included to remove the influence of unobserved differences across occupations that might affect the likelihood of people in the occupation getting elected to public office $\left(\pi_{o}\right)$. Results will also be presented for each occupation separately.

States vary in many potentially important dimensions likely to be correlated with occupational unionization rates and perhaps with the propensity to elect people from these occupations to the legislature. I use two approaches to deal with this threat to identification. First, I condition on (or control for) a variety of observable state characteristics that might influence the outcome $\left(x_{s}\right)$. These will be introduced and discussed throughout the results section but include a state's private sector unionization rate summarized in the last row of Table 1 Panel 2 and all variables in the fourth panel of Table 1. In this case, identification comes from the standard assumption that unobservable influences on outcomes $\left(\delta_{s}+\varepsilon_{o s}\right)$ are conditionally mean independent of observables $\left(u_{o s}, e_{o s}, x_{s} .1_{o}\right)$. Second, state fixed effects are included to control for all observable and unobservable state characteristics that influence the propensity to elect these occupations to the legislature. In this specification, the coefficients on state indicators measure the combined effects of $\gamma x_{s}+\delta_{s}$. Here, identification comes from assuming mean independence of idiosyncratic unobserved influences $\varepsilon_{o s}$ conditional on state, occupation, and observables varying across occupation within state $\left(u_{o s}, e_{o s}, 1_{s} .1_{o}\right)$. Results are very stable across specifications.

\section{Results}


For each occupation, Figure 1 presents a scatter plot of states' legislator share on the vertical axis and unionization rate on the horizontal. For each occupation, the best linear fit to the 50 data points is also displayed. Each state's data points are marked with its postal abbreviation. This gives a check on data quality and illustrates some basic patterns. For K-12 teachers, Minnesota has the highest share of teacher-legislators and a high unionization rate. Louisiana and South Carolina are low on both dimensions. In each occupation, there is a positive bivariate relationship between the two variables, such that states with higher unionization rates tend also to have higher legislator shares from that occupation. Table 2 presents these correlations. For instance, this means that the simple correlation between legislator share and unionization rate across states is 0.107 for teachers.

Table 3 presents the primary results. These are regression estimates of the relationship between legislator share and unionization rate using various sets of conditioning variables. In each case, there are 4 occupations and 50 states for a total of 200 observations. In specification 1, legislator share is regressed on unionization rate, employment share, and occupation fixed effects. Since legislator share and unionization rate both vary between 0 and 100 , the estimated unionization rate coefficient of 0.024 (0.009) suggests that going from 0 to 100 percent unionization would increase legislator share by 2.4 percentage points. ${ }^{7}$ Therefore, a 10 percentage point increase in union coverage for a state-occupation is associated with the occupation's share in the state legislature being 0.24 percentage points higher. Since the average state has about 147 legislators, this would imply an additional 0.4 legislators from that occupation, or if unionization were 10 percentage points higher in 10 states, then 4 states would be expected to have an additional legislator from that occupation.

The preferences of voters differ from one state to the next in ways that could drive both unionization rates and legislator shares. In simple form, perhaps more liberal states prefer both of these (teachers to be unionized and teachers in the legislature for instance). This would cause a positive association between teachers' legislator share and their unionization rate, without any real effect of teachers' unions on teachers' electoral prospects.

\footnotetext{
${ }^{7}$ Estimated standard errors are robust to heteroskedasticity and within-state correlation of unobserved influences across occupations.
} 
Consider however that the analysis is built on teachers, police, fire fighters, and construction workers. While it is quite plausible that more taste for unions and labor legislators is correlated with voters' liberalness, tastes for electing legislators from these different occupations may be negatively correlated. In fact, as reported in Table 2, states' share of teacher legislators is basically uncorrelated with the share of law enforcement $(r=0.028)$, fire fighter $(r=-0.043)$, or construction worker legislators $(\mathrm{r}=-0.056)$. This is despite the fact that all four occupations' unionization rates are generally positively correlated, and positively correlated with privatesector unionization rates. For instance, states' share of teachers unionized is correlated 0.905 with share of law enforcement officers unionized and 0.756 with share of private sector workers unionized. Further, the bivariate correlations of Obama vote margin with occupations' legislator shares suggest that more-conservative states tend to elect legislators with construction backgrounds $(r=-0.421)$ and more liberal states prefer the other occupations, though the latter correlations are much weaker.

Specification 2 of Table 3 adds two measures of state political climate meant to proxy for voter preferences: the percentage popular vote margin by which Obama beat McCain in 2008 and the union coverage rate of private-sector workers in the state. These constitute components of $x_{s}$ and do not vary across occupation within state. Conditional on these measures, the estimated relationship between legislator share and union coverage rate strengthens: 0.046 (0.011). This suggests that a 10 percentage point increase in union coverage is associated with an increase of 0.46 percentage points in legislator share - or about 7 additional legislators in ten states. That the relationship strengthens suggests that liberal voter tastes and private sector unionization rates are negatively correlated with legislator share. This may be due to a relatively stronger taste for construction, law enforcement and fire fighter legislators among more conservative states.

Specification 3 adds state demographic variables from the U.S. Census meant to give a richer characterization of state differences $\left(x_{s}\right)$. The goal is to include potential confounders, variables that both (1) influence occupational legislator shares and (2) are correlated with unionization rates. By bringing these into the analysis, the intent is to provide an unbiased estimate of the relationship between legislator share and unionization by removing the confounders' influence. The observables added are log of the resident population in 2010, population percent change from 2000 to 2010, percent of adults with educational attainment of at least a bachelors degree, 
percent of housing units that are owner-occupied, log of median household income, percent of people in poverty, and population density. Summary statistics for these are given in panel 4 of Table 1 . The estimated coefficient on unionization rate, $0.049(0.013)$, barely changes when these additional controls are added. If these observables were correlated with the remaining unobservable determinants of legislator shares, then this suggests that omitted variable bias would not pose a serious threat.

The models thus far have restricted each variable to have the same coefficient across occupations. However, this could be too restrictive; it may be that $\gamma_{\mathrm{o}} \neq \gamma_{\mathrm{o}^{\circ}}$. For instance, if liberal states greatly prefer teacher legislators and conservative ones prefer police officer legislators, then the coefficient on Obama vote margin might be positive for teachers and negative for police officers. Because this restriction might bias estimates, I relax this restriction in two ways.

First, Table 4 presents estimates from these models for each occupation separately. The same Table 3 specifications are replicated across columns 1,2, and 3 with one occupation in each row. For each of the 12 regressions, the estimated coefficient on unionization rate is presented. The estimated coefficients are all positive. This suggests that the relationship found in Table 3 is not driven by one of the occupations. There is some evidence that it is present in all of them, which is consistent with the theory. Remarkably with only 50 observations, many coefficients are significant. Estimates are relatively stable as additional state characteristics are added between specifications 1,2, and 3. Estimated coefficients are most statistically significant for police and fire fighters but largest in magnitude for construction workers in the richest specification. All point estimates are between 0.016 and 0.116 .

Second, in order to boost power by pooling information across occupations while allowing for maximal flexibility for the conditioning variables, specification 4 of Table 3 allows each occupation to have its own coefficient for each explanatory variable other than the occupation's unionization rate. The coefficient on unionization is restricted to be the same across occupations - in effect capturing the average conditional association across states between legislator share and unionization rate in these four occupations. The estimate, $0.031(0.015)$, remains in the narrow range obtained thus far. Because there are four coefficients estimated for each of the state-level variables and they are similar to those reported in Table 4, they are not reported. 
Finally, in specification 5, I shift from including state-level observable conditioning variables to using state fixed effects. This specification removes the influence of all state-level influences on legislator shares that are additive and common across occupations within state. The estimated effect of union coverage rate goes up slightly, to 0.054 (0.019), the largest estimate obtained in Table 3. One way to interpret this is that influences on legislator share that were unobserved in specifications 1-4 appear to be negatively correlated with occupational union coverage rates. In any case, the estimate is similar and plausible in magnitude.

The evidence presented here is based on cross-sectional partial correlations. Reverse causality stories are easy to come up with and hard to test. For instance, suppose that, for exogenous reasons, one state had a relatively high share of teachers in the legislature. They may have supported policies promoting the unionization of teachers. This would also induce a positive correlation between $y_{o s}$ and $u_{o s}$ but cause would run in reverse. However, the current study's design cannot address the issue definitively. If panel data on legislator occupations were available across time and there were variation in unionization rates across time, one might develop stronger evidence about this. ${ }^{8}$

\section{Conclusions}

This study develops new evidence about an effect of unions in society: their role in developing leadership from segments of society where it would not otherwise develop to the same extent. The empirical analysis found evidence consistent with the theory that unions promote members' electoral office-holding. To get a sense of the potential practical significance implied by these estimates, consider some simple extrapolations. Between 1977 and 2010, the unionization rate in the American economy halved from 24 to 12 percent. A linear extrapolation based on the estimates from this study suggests that this loss of 12 percentage points in unionization would have been accompanied by a reduction of about 44 in the number of legislators from union represented occupations. ${ }^{9}$

\footnotetext{
${ }^{8}$ Data on occupations of legislators from past decades would help but is not systematically available.

${ }^{9}$ This study estimates that a 1 percentage point reduction in union coverage rate is associated with approximately a 0.05 percentage point reduction in the share of state legislators from that occupation-state. There are a total of 7362 state legislators. So, $-12 *(.05) * 7362 \approx-44$.
} 
However, the fall in unionization occurred in the private sector and three of the four occupations studied here are public sector. In private-sector construction, there is evidence of a similar relationship but, with only 50 observations, the estimate is imprecise. It was difficult to find legislators from other well-defined private-sector occupations. This could be driven by a real difference in the operation of this process between public- and private-sector unions. Based on theory, public-sector unions should have a stronger incentive to exert political influence than private-sector unions. With state policies on public works spending and state prevailing wage laws, one could interpret construction as, to some extent, a mixed public-private case. It could also be that workers in other private sector occupations struggle to compete for elected office at the state level but that the process operates farther down the political ladder, in service in municipal or county office.

The estimates also suggest that unions' current unionization rate of 12 percent in the economy overall is associated with about 44 additional legislators from unionized occupations compared to an economy without any unions. This is almost a change of 1 legislator per state. Since unionization is not evenly distributed across states and legislative vote margins are often narrow, the true policy impact of this change may be larger in some states that would be suggested by the average.

Views on the social value of this role of unions echo many of the larger controversies around union political power. However, there are some different aspects here. To what extent are member-legislators serving as a conduit for bringing information into the policy process that is valuable and which would otherwise be excluded versus acting as rent-seeking special interests? Enriching formal political economy models featuring information aggregation (Piketty 1999) with correlations between electability and information content might illuminate the conditions under which this role of unions would be welfare enhancing. The debate about social value ultimately hinges on the open question of how any extra legislators from a given occupation influence policy. For instance, does having extra teachers in the legislature translate into wasteful, additional funding for education? Or, does it translate into wiser, better spending because it is more informed by practitioners' perspectives? Until these questions have firmer answers, the phenomenon of unions helping members rise to public elected office will remain a Rorschach test. Some will contemplate it and exclaim with delight, others with alarm. 
As the base of the labor movement narrows and becomes less "encompassing" (Olson 1982), its incentives will tilt less towards acting in the broader social interest and more towards acting in its own special interests. In any case, as unions decline, no other institution seems poised to play such an active role investing in the political development of middle class, working Americans, in organizing around their economic interests, or in serving as a political counter-weight to organized wealth. Of course, plenty stand ready to seek economic rents either way. 


\section{References}

Acemoglu, Daron. 2008. Oligarchic versus Democratic Societies. Journal of the European Economic Association. 6(1).

Addison, John T. and Barry T. Hirsch. (1989) Union Effects on Productivity, Profits, and Growth: Has the Long Run Arrived? Journal of Labor Economics. 7(1): 72-105

Bagetta, Matthew. 2009. Civic Opportunities in Associations: Interpersonal Interaction, Governance Experience and Institutional Relationships. Social Forces. 88(1): 175-199.

Bayne, Randy. North Valley Union Members and Candidates Connect. Labor's Edge. Accessed on January 31, 2012 at www.calaborfed.org/index.php/page/north_valley_union_members _and_candidates_connect/

Citizens United v. Federal Election Commission, 558 U.S. 08-205 (2010)

Commons, John R. 1934. Institutional Economics. MacMillan: New York, New York

Dark, Taylor E. III. 2000. Labor and the Democratic Party: A Report on the 1998 Elections. Journal of LaborResearch. 21(4): 627-640.

Deckman, Melissa M. 2004. School board battles: the Christian right in local politics. Georgetown University Press: Washington, D.C.

Delaney, John T., Marick F. Masters and Susan Schwochau. 1988. Unionism and Voter Turnout. Journal of Labor Research. 9(3): 221-236.

Delaney, John T., Jack Fiorito, and Marick F. Masters. 1988. The Effects of Union Organizational and Environmental Characteristics on Union Political Action. American Journal of Political Science. 32(3): 616-642.

DiNardo, John and David Lee. 2004. Economic Impacts of New Unionization on Private-Sector Employers: 1984-2001. Quarterly Journal of Economics. 119(4): 1383-1441.

Eaton, Susan. 1995. Union Leadership Development in the 1990s and Beyond. Workplace Topics. 4(2): 5-17.

Followthemoney.org. Accessed January 31, 2012.

Frandsen, Brigham R. 2011. The Effects of Public Sector Collective Bargaining Rights. Massachusetts Institute of Technology unpublished manuscript.

Frank, Larry and Kent Wong. Dynamic Political Mobilization: The Los Angeles Country Federation of Labor. WorkingUSA. 8(2): 155-181. 
Freeman, Richard B. and James L. Medoff. 1984. What Do Unions Do? Basic Books, Inc., Publishers. New York.

Freeman, Richard B. 2003. What Do Unions Do... To Voting? National Bureau of Economic Research Working Paper 9992.

Galbraith, John K. 1952. American Capitalism: The Concept of Countervailing Power. Houghton Mifflin: Boston, Mass.

Gregory, Robert G. and Jeff Borland. 1999. Recent developments in public sector labor markets. In: Orley C. Ashenfelter and David Card, Editor(s), Handbook of Labor Economics, Elsevier. 3(3): 3573-3630.

Greenhouse, Steven. Countering the Siege. New York Times. April 21, 2011.

Hinsz, Verlin B., R. Scott Tinsdale, \& David A. Vollrath. 1997. The Emerging Conceptualization of Groups as Information Processors. Pyschological Bulletin. 121(1): 43-64.

Hirsch , Barry T. and David A. Macpherson. 2002. Union Membership and Coverage Database from the Current Population Survey: Note. Industrial and Labor Relations Review. 56(2): 34954.

Hirsch, Barry T. 2004. What do unions do for economic performance? Journal of Labor Research. 25(3): 415-455.

Key, V. O. 1942. Politics, Parties, and Pressure Groups. Crowell and Company: New York

Lamare, Ryan M. 2010a. Union Influence on Voter Turnout: Results from Three Los Angeles County Elections. Industrial and Labor Relations Review. 63(3): 454-470.

--- 2010b. The Interactive Effects of Labor-Led Political Mobilization and Vote Propensity on Turnout: Evidence from Five Elections. Industrial Relations. 49(4): 616-639.

Lester, Patrick. Former teachers union president Kevin Deely aims to unseat Simmons in $131^{\text {st }}$ District. The Morning Call. January 31, 2012.

Lewis, H. Gregg. 1986. Union relative wage effects: A survey. University of Chicago Press: Chicago, Ill.

Lovenheim, Michael F. 2009. The Effect of Teachers' Unions on Education Production. Journal of Labor Economics. 27(4): 525-587.

Madison, James. 1787. Federalist \#10. The Federalist Papers at thomas.loc.gov/home/fedpapers/fed_10.html 
Mas, Alexandre and David Lee. 2009. Long-run impacts of unions on firms: new evidence from financial markets, 1961-1999. National Bureau of Economic Research Working Paper 14709.

Massachusetts AFL-CIO. 2011. Target 5000 - Union Members Holding Public Office access on February 1, 2012 at www.massaflcio.org/target-5000-union-members-holding-public-office

Masters, Marick F. and John T. Delaney. 1987. Union Political Activities: A Review of the Empirical Literature. Industrial and Labor Relations Review. 40(3): 336-353.

McCabe, Cynthia. Washington Educators Start Recruiting School Board Candidates. 4/25/11. Accessed on January 31, 2012 at www.educationvotes.nea.org/2011/04/25/washingtoneducators-start-recruiting-school-board-candidates/.

McDermott, Monica. Not For Members Only: Group Endorsements as Electoral Information Cues. Political Research Quarterly. 59(2): 249-257.

Moe, Terry M. 2011. Special Interest: Teachers Unions and America's Public Schools. Brookings Institution Press: Washington, D.C.

Mooretaxes. 2011. "Moore Calls WEAC the 'Wisconsin Mafia'" Online video clip posted 6/6/2011 on YouTube. Accessed 9/1/2011 at www.youtube.com/watch? $\mathrm{v}=\mathrm{n} 73 \mathrm{cMHLC7Gs \& feature=}=$ related

Mullins, Brody and John D. McKinnon. Campaign's Big Spender: Public Employee Union Now Leads All Groups in Independent Election Outlays. Wall Street Journal. Oct 20, 2010.

New Jersey AFL-CIO. 2012. Labor Candidate Winners. Accessed January 31, 2012 at www.njaflcio.org/files/njaflcio/COPE/Election\%20Victories/LaborCandidateWinners\%2012-1211.pdf

Nesbitt, Tom. 2001. Educating Labour's Professionals. Relations Industrielle/Industrial Relations. 56(4): 676-700.

Northwest Labor Press. Union members don't just vote - they run for office. May 16, 2008. Accessed at www.nwlaborpress.org/2008/5-16-08Candidates.html.

Olson, Mancur. 1965. The Logic of Collective Action: Public Goods and the Theory of Groups. Harvard University Press: Cambridge, Mass.

Olson, Mancur. 1982. The Rise and Decline of Nations: Economic Growth, Stagflation, and Social Rigidities. Yale University Press: New Haven, Conn.

Perez-Pena, Richard. Union Effort Is Grooming Candidates In New Jersey. New York Times. October 30, 2010. 
Piketty, Thomas. 1999. "The information-aggregation approach to political institutions." European Economic Review. 43: 791-800.

Piketty, Thomas and Emmanuel Saez. 2003. Income Inequality in the United States, 1913-1998. Quarterly Journal of Economics. 118(1): 1-39.

Pierson, Paul and Jacob S. Hacker. 2010. Winner-Take-All Politics: How Washington Made the Rich Richer and Turned Its Back on the Middle Class. Simon \& Schuster: New York, N.Y.

Quaglieri, Philip L. 1988. The New People of Power: The backgrounds and Careers of Top Labor Leaders. Journal of Labor Research. 9(3): 271-284.

Quist, Peter. Super PAC Contributors Impact State Campaigns. Followthemoney.org. February 10. 2012.

Radcliff, Benjamin and Patricia Davis. 2000. Labor Organization and Electoral Participation in Industrial Democracies. American Journal of Political Science. 44(1): 132-141.

Reynolds, Morgan O. 1984. Power and Privilege: Labor Unions in America. Universe Books: New York, N.Y.

Rose, Nancy L. 1987. Labor Rent Sharing and Regulation: Evidence from the Trucking Industry. Journal of Political Economy. 95(6): 1146-1178.

Sanbonmatsu, Kira, Susan J. Carroll, and Debbie Walsh. 2009. Poised to Run: Women's Pathways to the State Legislatures. Centers for American Women in Politics Working Paper. Rutgers University.

Skocpol, Theda. 2003. Diminished Democracy: from membership to management in American civic life. University of Oklahoma Press: Norman, Oklahoma

Smith, Adam. 1776. The Wealth of Nations. Strahan and Cadell: London, U.K.

Umhoefer, Dave. "State Senator Sheila Harsdorf says recall election opponent Shelly Moore opposes any limit of taxes." Journal Sentinel PolitiFact Wisonsin. July 27, 2011.

WeAreWisconsinPAC. 2011. "Shelly Moore: A Teacher For a Change" Online video clip posted 6/23/2011 on YouTube. Accessed 9/1/2011 at www.youtube.com/watch?v=hjfZlJE4Oa8.

Work in Progress. A New Target. December 10, 2001. Accessed on February 1, 2012 at www.aflcio.org/aboutus/thisistheaflcio/publications/wip/wip12102001.cfm?RenderForPrint=1

Workday Minnesota. Union members elected to the Minnesota Legislature in 2006 election. November 9, 2006. Accessed at www.workdayminnesota.org/index.php?article_1_100. 
Zullo, Roland. 2008. Union Membership and Political Inclusion. Industrial and Labor Relations Review. 62(1): 22-38. 
Table 1: Summary statistics for states

\begin{tabular}{|c|c|c|c|c|}
\hline Variables & Mean & SD & Min & Max \\
\hline \multicolumn{5}{|c|}{ Percentage of state legislators who worked in each occupation (Project Vote Smart) } \\
\hline Construction worker & 3.7 & 2.5 & 0 & 13.3 \\
\hline Fire fighter & 1.1 & 1.2 & 0 & 4.7 \\
\hline Police officer & 3.2 & 2.0 & 0 & 9.8 \\
\hline K-12 teacher & 12.4 & 4.3 & 4.3 & 22.7 \\
\hline Other & 79.6 & 5.6 & 67.4 & 89.1 \\
\hline Fraction of legislators missing occupation data & 3.4 & 4.8 & 0 & 25.5 \\
\hline \multicolumn{5}{|c|}{ Percentage of workers in each state-occupation belonging to unions (CPS) } \\
\hline Construction worker & 18.0 & 12.7 & 1.1 & 48.9 \\
\hline Fire fighter & 63.7 & 22.7 & 12.2 & 95.6 \\
\hline Police officer & 46.6 & 26.6 & 7.7 & 89.0 \\
\hline K-12 teacher & 50.7 & 18.6 & 14.0 & 77.3 \\
\hline Private sector & 7.3 & 3.6 & 2.0 & 15.9 \\
\hline \multicolumn{5}{|c|}{ Percentage of workers in each state employed in a given occupation (CPS) } \\
\hline Construction worker & 4.1 & 0.8 & 2.8 & 6.9 \\
\hline Fire fighter & 0.2 & 0.1 & 0.1 & 0.6 \\
\hline Police officer & 0.8 & 0.2 & 0.4 & 1.3 \\
\hline K-12 teacher & 3.5 & 0.5 & 2.5 & 4.6 \\
\hline \multicolumn{5}{|l|}{ State Characteristics } \\
\hline Obama vote margin in 2008 & 2.6 & 18.7 & -32.2 & 45.3 \\
\hline Population in 2010, millions & 6.2 & 6.8 & 0.6 & 37.3 \\
\hline Percent population change from 2000 to 2010 & 9.8 & 7.2 & -0.6 & 35.1 \\
\hline Percent with BA or higher degree & 26.8 & 4.7 & 17.1 & 37.8 \\
\hline Home ownership rate & 68.5 & 4.1 & 55.7 & 74.9 \\
\hline Median household income in $2009(\$ 1,000$ s) & 50.2 & 8.3 & 36.8 & 69.2 \\
\hline Poverty rate, 2009 & 13.8 & 3.0 & 8.6 & 21.8 \\
\hline Population density, per mile 2010 & 194.1 & 257.2 & 1.2 & $1,185.3$ \\
\hline
\end{tabular}


Figure 1: Scatter plot of unionization rate and fraction of legislators across states and best linear fit by occupation.
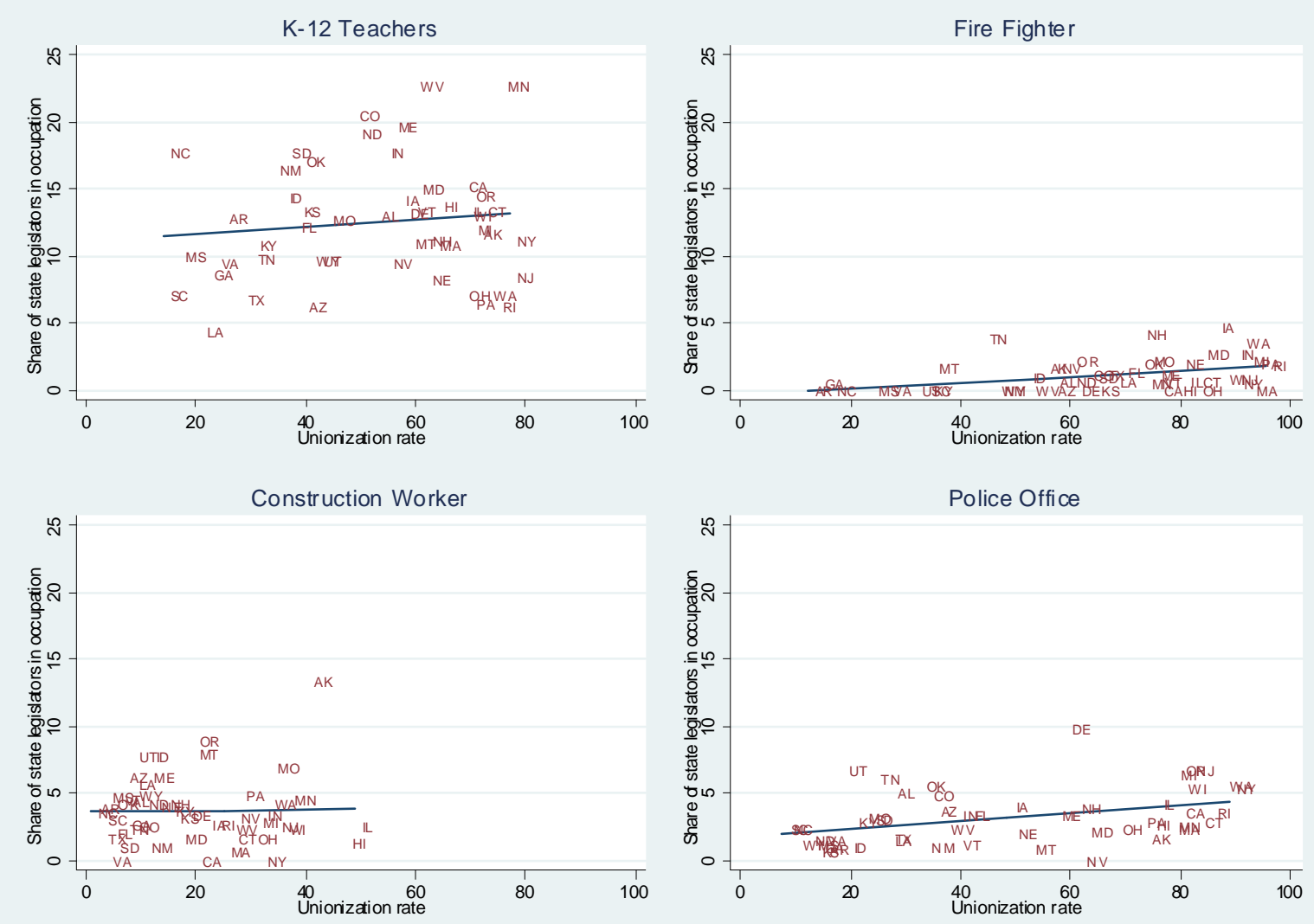
Table 2: Correlation of Variables

\begin{tabular}{|c|c|c|c|c|c|c|c|c|c|c|c|c|c|c|}
\hline \multirow{2}{*}{\multicolumn{2}{|c|}{ Variable }} & \multicolumn{2}{|c|}{ Correlations } & & & & & & & \multirow[b]{2}{*}{9} & \multirow[b]{2}{*}{10} & \multirow[b]{2}{*}{11} & \multirow[b]{2}{*}{12} & \multirow[b]{2}{*}{13} \\
\hline & & 1 & 2 & 3 & 4 & 5 & 6 & 7 & 8 & & & & & \\
\hline \multicolumn{15}{|c|}{ State's share of legislators who have worked as } \\
\hline 1 & Teachers & 1.000 & & & & & & & & & & & & \\
\hline 2 & Police Officers & 0.028 & 1.000 & & & & & & & & & & & \\
\hline 3 & Fire Fighters & -0.043 & 0.254 & 1.000 & & & & & & & & & & \\
\hline 4 & Constrution Workers & -0.056 & -0.023 & 0.163 & 1.000 & & & & & & & & & \\
\hline & & & & & & & & & & & & & & \\
\hline \multicolumn{15}{|c|}{ State's share of workers in a union } \\
\hline 5 & Teachers & 0.107 & 0.368 & 0.271 & 0.012 & 1.000 & & & & & & & & \\
\hline 6 & Police Officers & -0.046 & 0.377 & 0.252 & -0.092 & 0.905 & 1.000 & & & & & & & \\
\hline 7 & Fire Fighters & -0.000 & 0.327 & 0.392 & -0.211 & 0.770 & 0.741 & 1.000 & & & & & & \\
\hline 8 & Constrution Workers & 0.053 & 0.214 & 0.148 & 0.019 & 0.772 & 0.757 & 0.611 & 1.000 & & & & & \\
\hline 9 & Private Sector & 0.017 & 0.255 & 0.130 & -0.060 & 0.756 & 0.760 & 0.585 & 0.917 & 1.000 & & & & \\
\hline & & & & & & & & & & & & & & \\
\hline \multicolumn{15}{|c|}{ State's share of workers employed as } \\
\hline 10 & Teachers & -0.035 & -0.387 & -0.243 & 0.106 & -0.191 & -0.250 & -0.188 & -0.296 & -0.287 & 1.000 & & & \\
\hline 11 & Police Officers & -0.201 & 0.030 & -0.160 & -0.221 & -0.251 & -0.086 & -0.082 & -0.101 & -0.003 & 0.080 & 1.000 & & \\
\hline 12 & Fire Fighters & -0.202 & -0.132 & 0.031 & 0.101 & -0.035 & 0.092 & 0.026 & 0.041 & 0.006 & -0.029 & 0.149 & 1.000 & \\
\hline 13 & Constrution Workers & -0.063 & -0.245 & -0.240 & 0.137 & -0.435 & -0.384 & -0.526 & -0.317 & -0.271 & -0.224 & 0.321 & 0.099 & 1.000 \\
\hline 14 & Obama vote margin & 0.088 & 0.218 & 0.073 & -0.421 & 0.591 & 0.709 & 0.555 & 0.508 & 0.531 & -0.155 & 0.032 & 0.037 & -0.225 \\
\hline
\end{tabular}


Table 3: Regression analysis of relationship between legislator share and unionization rates

\begin{tabular}{|c|c|c|c|c|c|}
\hline \multicolumn{6}{|c|}{ Dependent Variable: fraction of legislators in that state-occupation } \\
\hline Specification & 1 & 2 & 3 & 4 & 5 \\
\hline \multicolumn{6}{|c|}{ State-occupation variables } \\
\hline Union membership rate & $\begin{array}{c}0.024 * * * \\
(0.009)\end{array}$ & $\begin{array}{l}0.046 * * * \\
(0.011)\end{array}$ & $\begin{array}{c}0.049 * * * \\
(0.013)\end{array}$ & $\begin{array}{l}0.031 * * \\
(0.015)\end{array}$ & $\begin{array}{l}0.054 * * * \\
(0.019)\end{array}$ \\
\hline Employment share & $\begin{array}{c}0.384 \\
(0.368) \\
\end{array}$ & $\begin{array}{c}0.286 \\
(0.363)\end{array}$ & $\begin{array}{c}0.410 \\
(0.426) \\
\end{array}$ & $\begin{array}{c}\text { Yes* } \\
\text { occupation }\end{array}$ & $\begin{array}{c}0.502 \\
(0.544)\end{array}$ \\
\hline \multicolumn{6}{|l|}{ State variables } \\
\hline Obama vote margin & & $\begin{array}{r}-0.023^{*} \\
(0.012) \\
\end{array}$ & $\begin{array}{l}-0.014 \\
(0.015) \\
\end{array}$ & $\begin{array}{c}\text { Yes* } \\
\text { occupation }\end{array}$ & \\
\hline $\begin{array}{l}\text { Private-sector union } \\
\text { membership rate }\end{array}$ & & $\begin{array}{l}-0.075 \\
(0.062)\end{array}$ & $\begin{array}{c}0.022 \\
(0.064)\end{array}$ & $\begin{array}{c}\text { Yes* } \\
\text { occupation }\end{array}$ & \\
\hline Log of population & & & $\begin{array}{l}-0.294 \\
(0.230)\end{array}$ & $\begin{array}{c}\text { Yes* } \\
\text { occupation }\end{array}$ & \\
\hline Population growth & & & $\begin{array}{c}0.031 \\
(0.037)\end{array}$ & $\begin{array}{c}\text { Yes* } \\
\text { occupation }\end{array}$ & \\
\hline Percent with bachelors & & & $\begin{array}{c}0.109 \\
(0.093) \\
\end{array}$ & $\begin{array}{c}\text { Yes* } \\
\text { occupation }\end{array}$ & \\
\hline Home ownership rate & & & $\begin{array}{l}0.105^{* * *} \\
(0.045)\end{array}$ & $\begin{array}{c}\text { Yes* } \\
\text { occupation }\end{array}$ & \\
\hline Log median income & & & $\begin{array}{l}-3.839 \\
(3.782)\end{array}$ & $\begin{array}{c}\text { Yes* } \\
\text { occupation }\end{array}$ & \\
\hline Poverty rate & & & $\begin{array}{l}-0.050 \\
(0.165)\end{array}$ & $\begin{array}{c}\text { Yes* } \\
\text { occupation }\end{array}$ & \\
\hline Population density & & & $\begin{array}{c}-0.002 * * \\
(0.001)\end{array}$ & $\begin{array}{c}\text { Yes* } \\
\text { occupation }\end{array}$ & \\
\hline \multicolumn{6}{|l|}{ Occupation fixed effects } \\
\hline Law enforcement & $\begin{array}{c}-8.104 * * * \\
(1.351)\end{array}$ & $\begin{array}{c}-8.283 * * * \\
(1.332)\end{array}$ & $\begin{array}{c}-7.930 * * * \\
(1.453) \\
\end{array}$ & $\begin{array}{l}-122.781 \\
(148.951)\end{array}$ & $\begin{array}{c}-7.659 * * * \\
(1.781)\end{array}$ \\
\hline Construction & $\begin{array}{r}-8.184 * * * \\
(0.769)\end{array}$ & $\begin{array}{c}-7.439 * * * \\
(0.736)\end{array}$ & $\begin{array}{c}-7.390 * * * \\
(0.823)\end{array}$ & $\begin{array}{l}-99.774 \\
(186.908)\end{array}$ & $\begin{array}{c}-7.296 * * * \\
(1.018)\end{array}$ \\
\hline Fire fighter & $\begin{array}{c}-10.394 * * * \\
(1.524)\end{array}$ & $\begin{array}{c}-10.992 * * * \\
(1.547)\end{array}$ & $\begin{array}{c}-10.630 * * * \\
(1.759) \\
\end{array}$ & $\begin{array}{c}-89.797 \\
(154.892)\end{array}$ & $\begin{array}{c}-10.382 * * * \\
(2.231)\end{array}$ \\
\hline State fixed effects & $\mathrm{N}$ & $\mathrm{N}$ & $\mathrm{N}$ & $\mathrm{N}$ & $\mathrm{Y}$ \\
\hline Adj. $R^{2}$ & 0.723 & 0.731 & 0.752 & 0.792 & 0.727 \\
\hline $\mathrm{N}$ & 200 & 200 & 200 & 200 & 200 \\
\hline
\end{tabular}

Coefficient estimate significant at: *10\%; ** 5\%;*** $1 \%$.

Within-state correlation corrected standard errors in parentheses. 
Table 4: Estimates of unionization rate coefficient for specifications 1, 2 and 3 conditional on each occupation separately.

\begin{tabular}{|l|c|c|c|}
\hline \multirow{2}{*}{ Dependent Variable: fraction of legislators in state-occupation } \\
Occupation & \multicolumn{3}{|c|}{ Specification } \\
\hline Teachers & 0.024 & 0.046 & 0.016 \\
& $(0.035)$ & $(0.052)$ & $(0.069)$ \\
\hline Police Officers & $0.029^{* * *}$ & $0.041^{* *}$ & $0.039^{*}$ \\
& $(0.009)$ & $(0.015)$ & $(0.019)$ \\
\hline Construction & 0.014 & 0.116 & 0.089 \\
& $(0.039)$ & $(0.071)$ & $(0.062)$ \\
\hline Fire fighters & $0.021^{* * *}$ & $0.029^{* * *}$ & $0.023^{* *}$ \\
& $(0.006)$ & $(0.008)$ & $(0.009)$ \\
\hline & \multicolumn{3}{|c|}{ Controls Included? } \\
\hline Obama margin and private- & \multicolumn{3}{|c|}{$\mathrm{Y}$} \\
sector unionization & $\mathrm{Y}$ & $\mathrm{Y}$ \\
\hline Other state demographics (5) & \multicolumn{3}{|c|}{$\mathrm{Y}$} \\
\hline Conditions on occupation & Y & $\mathrm{Y}$ \\
\hline
\end{tabular}

Coefficient estimate significant at: *10\%; ** 5\%;*** $1 \%$.

Heteroskedasticity-robust standard errors in parentheses. Each cell presents the unionization rate coefficient estimate from a separate regression with specification analogous to those in Table 3. By row, each occupation is used as a separate sample. $\mathrm{N}=50$ in all 12 regressions. 